\title{
(1) 中耳手術に扔ける内耳㾇
}

\section{瀧本 勲・ 犬塚一男・杉山貴志子・川出博彦・井沢一宏（愛知医大）}

目的 中耳手術においては骨削開時のノミによる内 耳振温や骨折, ドリルによる内耳瘦孔や耳小骨との接 触, アブミ骨周囲の病変除去時の強いゆり動かしや靶 帯損傷, PORP やコルメラ使用時のアブミ骨宿没など の技術的問題による予期せざる内耳溲孔その他を生 じ，術後の一過性あるいは恒久的内耳障害に悩む場合 がありうる．今回，我々は上記条件について動物実験 を行うと共に, 術後内耳障害を示した 1 臨床例及びド リル使用の有無と内耳障害発生の関係を検討し, 今後 への注意喚起の一助とした。

方法と結果 A. プライエル反射正常のモルモット 使用. 1) キヌタ骨にダイヤモンドバー接触. 1 分接触 ではラセン器の剥離を認めたが, 1 秒でも SEM では聴毛消失を来している.2）外耳道附近をノミで打 撃. 蝸牛骨壁や前庭半規管部の骨折や出血のみならず 小脳橋角附近の出血を認め, 更にこれらの結果と考え られ, 浒進する難聴病態になりうる蛊牛空附近の骨新 生やラセン神経節の変性を認めた。3）アブミ骨のゆり 動かし. 輪状勒带には余り変化は出ていないが聴毛の 捻れ, ラセン器の平坦化を疑わせる所見を示した。 4) アブミ骨の迷路内脱落. 直後ではアブミ骨周辺に異常 はなくライスネル膜の受動的膨隆を示すのみである。

7 日後では好中球の浸潤を伴う線維化が始まり, 基底 回転での形態変化とも思われる所見があったが, SEM での聴毛排列には異常を認めなかった.5）迷路骨胞の 瘦孔作成. ダイヤモンドバーを用いた。 7 日後ではき れいな線維化により瘦孔は閉鎖を示した(図 1).SEM では聴毛の乱れを示したがバーの回転が外リンパに強 い流れを来し中央階に影響を与えたと考えられた。

B. 臨床例 アブミ骨周辺の操作が原因と考えられ る術後一過性の内耳障害例を示し, またバー使用有無 と術後内耳障害発現の関係を検討した。特にバー使用

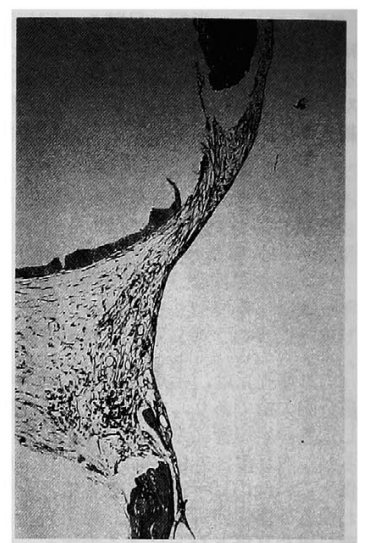

図 1 瘦孔部位の線維化 閉鎖 (右：中耳側)

例に多く障害が出ているものではなかった.

まとめ 1. 中耳手術中に用いる器具, 操作の方法に よっては内耳内に明確な変化を来しうる.2. 骨折は迷 路表面のみならず深部にもおこりうる. 出血は内耳の みならず頭蓋内にもおこりうる.3. アブミ骨の操作如 何によっては聴毛の捻れゃラセン器の変化を来しう る。迷走骨胞の瘻孔は線維化閉鎖したがバーの用い方 により聴毛も変化をおこしうる.4. 実際臨床でも上記 変化の可能性があり早い発見と治療が必要である.

\section{(2) 真珠腫と内耳瘻孔}

$$
\text { 中 野 雄 一 (新潟大) }
$$

過去23年間に当科で行われた真珠腫初回手術例 418 耳と慢性中耳炎初回手術例 255 耳について瘦孔の出現 率を調べたところ, 前者は 28 耳 $6.7 \%$, 後者は 4 耳 1.6 \%であった。このように中耳炎合併症としての内耳㾇 孔は，真珠腫による場合がほとんどである。したがっ て中耳真珠腫の診療にあたつてまず気になるのが瘦孔 の有無である. そこでもし瘦孔の存在が疑われたら次 に問題となるのが㾇孔の処理である.もちろん手術的 に処理するわけであるが, 病変が真珠腫ということで 術式の選択も大きな問題となる。すすなわち㾇孔の予測
と予測された痶孔に対する手術的な取り扱いである. 今回, この 2 点について前述せる真珠腫初回手術症例 を瘦孔例と非瘦孔例に分け, 種種な観点から検討を加 えた。

1. 霆孔の予測（とのような真珠腫で瘦孔が生じや すいか)

瘦孔例の手術時年齢は40歳以上に多く, 椎患年数も 平均29年 8 力 と長期にわたるものがほとんどであっ た.めまいの自覚, 眼振検査などの情報は確実性に乏 しく，わずかに定型的瘦孔症状のみが瘦孔存在の指標 